\title{
Engaging the history of religions - from an Islamic studies perspective ${ }^{1}$
}

\author{
SUSANNE OLSSON \\ Stockholm University \\ LEIF STENBERG \\ Lund University
}

\begin{abstract}
The future and relevance of the history of religions discipline in the Swedish context has been discussed lately. This article is a response to this debate from an Islamic studies perspective. The authors argue that the history of religions discipline may become more relevant if a more self-critical approach is adopted, an interdisciplinary attitude upheld, and if there is an openness to learn from other disciplines studying religion such as Islamic studies. Moreover, a reflection on 'history' in the history of religions is necessary if elitism and a too narrow definition of the discipline are to be avoided. Furthermore, the article addresses the question as to whether or not scholarly engagement in disseminating findings in public should be an intellectual and moral requirement.
\end{abstract}

Keywords: History of Religions, Study of Religions, Islamic Studies, critical perspectives, engaged research

This article seeks to engage with a broader debate on the study of religions that is currently influential in the discussions among scholars of the field in Sweden and perhaps elsewhere. To set the stage we highlight features relating to theory and method in the study of religions that we believe to be significant. This is followed by a brief discussion of the context of the relevant research in general. We then address the criticism sometimes expressed that scholars in the field of Islamic studies are primarily concerned with the 'contemporary' and the underlying presumptions of such statements.

1 The authors of this article specialise in contemporary Islamic studies. This article was presented as a draft at a workshop concerning the current status of research within the discipline of the history of religions at the Royal Academy of Letters in Sweden, 20-21 February 2014. The authors were asked by the conveners to give an introductory talk at a panel discussion with the title 'Research Policies versus Politicization of Religion'. A longer draft was later presented at the workshop 'The Trembling Tradition of the Humanistic Study of Religions', 11-12 December 2014, at Linneaus University, Sweden. 
We then deal with scholarly involvement in the politicisation of religion and the involvement of scholars studying religion in public discussion. In the concluding paragraphs we discuss various approaches to the study of religion and especially our critical view of the history of religions as an academic field. Underpinning this discussion is an exploration of issues related to our scholarly choices and perspectives that concern how scholars within the study of Islam at large study 'religion' today.

Current global events have embedded Islam in political agendas and the political attention given to it influences not only popular interests and the media, but also the understanding of Islam by Muslims and non-Muslims alike. These developments have given rise to increased demand for scholars studying Islam and Muslims and their broader social and cultural context. This is clear at universities, where scholars from a variety of disciplines, but focusing on the study of Islam, are often sought after to address students' need to learn about Islam, but also to serve a broad and varied public interest, in the media, and among civil servants and policy makers. ${ }^{2}$ It is our view that such a development is not necessarily a threat to the study of religion in general.

Today there is an interest in religion, religious expression, practice, and experience in several disciplines and by scholars far beyond the study of religions and the specific discipline of the history of religions. As a result, scholars defining themselves as historians of religions face fierce competition in the quest for funding and in the process of Swedish universities' structural reorganisation. The latter makes the future for the history of religions discipline seem bleak for a variety of reasons. One is universities' preference for more inclusive labels such as 'religious studies' or the 'study of religions'. ${ }^{3}$ Another is more internal and concerns the object of study within the discipline and what to be a historian of religions implies.

Linked to the idea of the politicisation of religion as well as the identity of the history of religions as a discipline is the question of whether or not scholars should engage in public debates on religious matters. The question is whether the ideal is to individually conduct research in ivory towers, disseminate the results as neutrally or reflexively as possible, and then remain largely silent - apart from engaging in discussion with students and,

\footnotetext{
2 In discussing the field of Islamic Studies Edward E. Curtis IV (2014) has observed that the large number of disciplinary perspectives represented in Islamic studies is what makes the contemporary study of Islam intellectually dynamic and vibrant.

3 Swedish: 'religionsvetenskap'. In Sweden, the history of religions as a separate discipline is only found at the universities in Lund (Center for Theology and Religious Studies), Stockholm (Faculty of Humanities) and Uppsala (Faculty of Theology).
} 
perhaps, colleagues. Some of us may present our research in popular forms - which appear to be in demand, at least in Sweden, if the questions about the dissemination of research we are constantly asked in external and internal evaluations and by funding agencies are an indication. In this connection we should make an important distinction: here we are not primarily interested in questions about the dissemination of research, but rather in a more active engagement with society at large, especially in public debate, even though the public or audience for these two activities coexist and overlap. This latter remark notwithstanding, in this discussion we intend to examine what it means to be a critical scholar and how (or if) to be/become engaged. Hypothetically a self-critical approach would be an advantage in a discussion regarding the stances scholars of the history of religions take towards questions pertaining to their public role or to their function as critical and/ or engaged scholars. However, it has to be acknowledged that there is, at least potentially, a difference between being critical and being engaged: such a self-critical attitude would be beneficial in a reflection on individual and collective approaches to the history of religions as an academic field. One thing is certain: the lack of academic entrepreneurship capable of building structures in the collective interest of the field is more than evident. Few historians of religion have engaged themselves in building institutions, centres, or any other academic framework that might improve the broader environment and the quality of research through the establishment of a larger critical mass in the Swedish context.

As far as we are aware there are no established practices or strategies pertaining to the study of religion that reflect the interests of the state, the public, and academia. The term 'research policies' can certainly be understood in various ways and relate to strategies established by public or private funding agencies, but also to local circumstances at universities and to the order of priorities identified by individual scholars. However, there is no doubt that, where Sweden is concerned, there are no broader national research policies in regard to the study of religions.

\section{Engaging with the fields of the study of religions}

Theory, in the words of Catherine Bell, 'is not just a tool to open a can of data. It is the gestalt against which data emerges, with the ability to illuminate something of the value of the methodological principles informing the context.' (Bell 2006, 324.) In the history of religions vivid discussions on theory and method are commonplace, and the need to acknowledge how 
one's perspectives and choice of methods and theories affect the analysis of the empirical material is generally agreed. In the broader field of the study of religions we find several subfields and various approaches ranging from reductionist to more essentialist perspectives on 'religion'. Subfields and approaches also relate to how the objects of our studies are to be approached in terms of engagement and the range of influence they may have upon our analyses. Depending on how scholars answer such questions, the result of one's research may be very different. Some scholars advocate a strict 'outsider' perspective, while some advocate a more empathetic and engaged approach towards an 'insider's' perspective. Such methodological issues are presently discussed among scholars of Islam in different disciplines, but also across disciplinary boundaries. This is perhaps more urgent in this field than in others because of the general currency of Islamophobic attitudes and the associated risk of scholars being accused of holding racist and Orientalist views when conducting research construed as 'too critical', whether by Muslims or non-Muslims. Furthermore, the diversity of disciplines studying common empirical fields is an additional factor that contributes to theoretical and methodological debates and renewal.

Within the framework of a secular academic approach 'religion' has to a large extent been defined in terms of beliefs, internal conditions, and systems of symbols. However, more recently, actions and behaviour have been added to the definition. Moreover, several scholars feel that the place of power and agency in analysing 'religion' needs to be strengthened - this follows the call for a scientifically founded critical approach (Asad 1993; McCutcheon 1997; Lincoln 2003). Talal Asad shows how the term 'religion' has been conceptualised in an essentialist manner as a transhistorical and irreducible transculturally distinct autonomous sphere. Asad is critical of Clifford Geertz's (1973) well-known definition of religion that refers to interior moods and motivations with a primary focus on faith. Asad's critique of definitions such as Geertz's is largely based on the separation of religion from power. He regards such definitions as part of a post-Enlightenment development in which belief became the only legitimate space for religion. Peter Beyer builds on similar ideas. He identifies key aspects of the postmodern era by describing the development of structurally differentiated systems with their own specific functions such as economy and jurisprudence. In Beyer's perspective challenges unsolved by other systems leave space for religion to handle existential issues (Beyer 1994; Beyer 2006). However, the ideas presented by Asad suggest that Beyer's perspective could be discussed and, indeed, critically elaborated and complemented, since the idea of a 
compartmentalisation is problematic in analysing, for instance, contemporary piety movements in which 'religion' is not limited to a specific space in society. This also supports the view that it is essential to consider power and agency in scholarly work, for example in regard to the significance of non-Muslims' views for the understanding of Islam in general. Indeed, current discussions in societies about Islam contain a variety of non-Muslim actors expressing views about Islam that in a discursive mode becomes part of how Islam is understood by non-Muslims as well as Muslims.

Moreover, Talal Asad shows how definitions of the kind advocated by Clifford Geertz are effectively developed from a Christian and primarily protestant perspective that has made Christianity the model of religion, reflecting a Eurocentric and Christian perspective. Asad states that all definitions are bound by their context. This permits him to be sceptical of or reject universal definitions of any kind, a position that finds expression in his well-known statement:

My argument is that there cannot be a universal definition of religion, not only because its constituent elements and relationships are historically specific, but because that definition is itself the historical product of discursive processes (Asad 2006, 29).

The quotation underlines Asad's position that every definition is contextually and discursively bound. Andrew McKinnon's rejection of essentialist definitions expresses a similar understanding:

[T]here is no essence of religion outside the discourse of religion. There is no religion per se, pour soi, or an sich. Of course, concepts like 'religion' have real social consequences, and are important constitutive elements in the construction of global, national, and local social formations. In that sense, however, there is such a 'thing' as religion - or at least, it is a term we cannot do without, and we 'know' what it means (McKinnon 2002, 81). ${ }^{4}$

McKinnon focuses on the usage of 'religion' and the role of 'religion' as part of various constructions, thereby suggesting that religions are not autonomous or immutable social realities but components of various sociohistorical articulations or constellations. Hence, power issues are central to our understanding of religion and should not be neglected. The term

4 For an example of an analysis of a process in which Islam is discursively produced, see Stenberg 1996. 
'power' can, of course, be understood in many ways and exist at several levels. It pertains to the distribution of political power in society, but also at a more foundational societal and private level, regarding, for example, gender roles. As an academic field the study of religions can benefit from a social constructionist perspective that contributes to highlighting power discourses involved in religious interpretations in a national context. In the case of Muslim piety movements in Egypt and Syria movement actors have become involved in power struggles at several social and political levels. Islamisation processes in a society affect the governmental policy of Islam as well as other Islamic positions in a dialectical relationship, with a resulting increase of Islamisation (Bayat 2007; Olsson 2015). 'Islam' therefore cannot be seen as a self-contained and internally defined phenomenon or religion. Hence, the dialectical relationship affecting positions on Islam includes societies at large regardless of whether institutions, movements, or individuals are Muslim or not. Furthermore, the relationship between power and religion can also be played out in regard to the performance of rituals within a family or what is commonly understood as 'our history' within a certain local group of believers.

Social constructionist approaches are, according to Vivien Burr, linked to each other by what she calls a 'family resemblance', which is constituted by common assumptions or approaches. One foundational social constructionist approach is a critical stance towards taken-for-granted knowledge. An inherent critique of positivism and empiricism is, in Burr's view, unavoidable and leads to a perspective in which all categories used are regarded as arbitrary and constructed, as well as historically and culturally specific. Like Asad Burr rejects universal definitions. Moreover, knowledge and truth are understood as constructed and sustained in human social interaction and processes. Consequently, a perspective that calls for contextualised analyses in which knowledge and truth are seen as negotiated understandings is required (Burr 2003, 2ff). Such a perspective naturally also affects conceptualisations of terms such as 'religion'.

To some extent it seems that the problems concerning various definitions of 'religion' are impossible to circumvent. Catherine Bell critically comments on the discussion that the study of religions does not really have a field since we have not agreed upon a common definition of 'religion' (Bell 2006, 316). She cites Mark C. Taylor, who wrote: 'The field of religious studies - if it is a field - is in a perpetual state of crisis because it can neither define its object of study nor agree on distinctive methods or strategies of interpretations.' (Taylor 2004, B4.) Bell states that if there were a common definition, we would 
scarcely make any progress, but rather stagnate. 'If the goal is to determine which theory of religion is the best, we would have to ask best for what,' she argues (Bell 2006, 324). Bell holds that: 'Critical terms are not critical because they contain answers but because they point to the crucial questions at the heart of how scholars are currently experiencing their traditions of inquiry and the data they seek to encounter.' (Bell 1997, 220.) Bell's statement indicates that she holds the idea that questions are more significant than answers, but also that the questions mirror the status of a certain scientific tradition in regard to the experience of researchers and their choice of empirical material.

\section{No view comes from nowhere}

For Thomas Nagel, although every research project is to some extent ethnocentric, the researcher cannot simply abdicate from engaging in complex debates. His answer to the dilemma between ethnocentrism and silence is expressed as follows: 'In understanding that there is no 'view from nowhere' (...), reflexivity answers the question by whom, for whom and for what reasons, and allows for criticism from the same place as well as from other places.' (Flood 1999, 40. See also Flood 1999, 148-149) In Nagel's opinion reflexivity is an important analytical tool in the sense that it can be deployed to help the researcher or scholar avoid merely reproducing what 'insiders' may have to say. His statement acknowledges the risk of being criticised by 'insiders' (or 'stakeholders', as we would prefer to say) 5 as an expression of reductionism (see McCutcheon 2001, 21ff, a chapter entitled 'Redescribing "Religion" as Social Formation'; see also Waardenburg 2003). Unquestionably, any analysis can be conducted in a way a stakeholder may not like. However, if they are stakeholders linked to a particular confession they should not necessarily have the right to determine how their religious practice or theology should be analysed or scientifically understood.

5 In order not to display 'insiders' and 'outsiders' as coherent or dichotomies the term 'stakeholder' is chosen and conceptualised to emphasise an inclusive approach and the interplay between representatives of religions (the faithful, the priests, the 'ulama') and societies at large. At one level a discursive development of public debates on Islam and its meaning certainly contains a variety of personal or impersonal stakeholders such as local imams and nationalist right wing parties - all of them influencing how Islam is understood in the public space on an ongoing basis. Hence, stakeholders with different interests overlap in common discourses, but more general debates on 'Islam' containing a number of different stakeholders may also influence specific theological and local interpretations of Islam in the sense that they colour what is seen as significant from a confessional milieu and in need of an 'Islamic' answer. An example of the latter is the ambition among Muslim scholars to understand Islam in relation to terms such as 'democracy', 'human rights', and 'gender'. 
It is clear that to a stakeholder an analysis of processes of Islamisation may present an image that he or she totally rejects. Scholars may conclude at times that something looks like the Islamisation of a thing or phenomenon usually perceived as un-Islamic, while others may regard this as a colonialist or Orientalist conclusion. ${ }^{6}$

A relevant question therefore concerns the role of stakeholders and the extent to which they influence our work - our conceptualisation of terms and perspectives. It is clearly important to discuss the scholarly stance regarding dialogue and empathy and how scholars respond when a stakeholder reacts negatively to scholarly writing. In this context it is important to stress how scholars handle and discuss stakeholders' opinions about research. Above all, the impossibility of a universal definition of religion has been noted. This includes a rejection of essentialist perspectives and asserts the need for scholars to be engaged in robust and critical inquiry. Being critical does not mean that a study must be negative or hostile to stakeholders' interpretations of a religious tradition or attempts from left or right wing political parties to determine what 'Islam' really states about a specific question. It is rather an analytical attempt to remain as neutral in regard to confession and/or politics as possible, and not allow stakeholders to control either the analysis or the scholarly language.

Russell T. McCutcheon discusses the conflictual situations that can occur when scholars negotiate and try to resolve issues of difference with the object of study. He shows how scholars with an engaged and empathetic approach can criticise other approaches for being dehumanising in studying people's religious practices and traditions in ways believers have not authorised. This would be to neglect the 'moral requirement' of gaining consent when theorising and analysing: an engagement in a consensual conversation is called for (McCutcheon 2006, 721-722). This resembles an updated version of Wilfred Cantwell Smith's well-known and highly problematic phrasing that 'no statement about a religion is valid unless it can be acknowledged by that religion's believers' (Smith 1959, 42 in McCutcheon 2006, 722). Such a statement is based on a fixed view of 'religion', or at least on supporting a specific version of a religious tradition. Such an attitude carries several problems that not only concern definitions of religious practices and traditions and their history, but also how 'religion' is produced.

McCutcheon discusses this in relation to the question of who is entitled to feel offended by scholarly work. Any answer to such a question

6 See Johnson 2008 for a discussion on scholarship concerning Hawaiian traditions, which illuminates discussion on authenticity and identity as well as conflicts between insider and outsider accounts. 
demonstrates how scholars normalise standards for belonging to a specific group (McCutcheon 2006, 723, note 6). Undoubtedly, a consequence is that such a scholarly position must engage in debate and conflict regarding interpretative authority. This discussion is developed in an article in which McCutcheon uses the phrase 'no cost Other', in which he problematizes the definition of Otherness (McCutcheon 2006, 730ff). He asks if it is not the case that methods differ depending on the object of study and if a scholar should be silent if he or she cannot say anything positive about the people studied (McCutcheon 2006, 732). In his opinion it is quite natural to choose to study objects that one can feel empathy towards or that are not too different. Moreover, McCutcheon's article also problematizes that if a scholar chooses to study a disliked phenomenon then it would probably be much more difficult to maintain neutrality and to allow those studied to represent themselves. He shows that the terminology used often illustrates when scholars are dealing with 'no cost Others' or other Others (McCutcheon 2006, 746 note 34). In a similar vein Asef Bayat notes the common practice of not speaking about the terms 'religious' and 'nonreligious', but rather differentiating between 'religious' and 'more religious'. This 'over-religiosity', as Bayat calls it, is often expressed in terms like 'fundamentalism', 'revivalism', 'conservatism', 'fanaticism', and 'extremism' (Bayat 2007, 1).

\section{Human and humane}

Those searching for a dialogue between scholars and those they study may risk not only striving for consent but also assent, allowing informants to control the scholar's research. Russell T. McCutcheon finds it difficult to believe that our research subjects would consent to being, from their point of view, misrepresented (McCutcheon 2006, 725 and note 8). He states that the approach of consensual conversation belongs to a liberal humanist tradition where the conversation, i.e. the study of religions, 'ha[s] something to do with its being both deeply human and humane' (McCutcheon 2006, 726) and that there is an underlying commonality that all humans share 'making them all participants in a common dialogue that addresses and, ideally, overcomes the particularities that might otherwise divide them' (McCutcheon 2006, 726). The study of religions thus becomes something that will 'bridge the gap' between the Self and the Other (McCutcheon 2006, 727 ) in the sense of trying to engage in a 'mutually beneficial dialogue with a consenting Other' (McCutcheon 2006, 728). This is a discipline that not only explains that there is a common bond between human beings, but also 
claims that this bond is religion and that the study of religions can explain its true character.

Furthermore, following a social constructionist approach, McCutcheon's outlook is linked to critical remarks on scholarly approaches to the term 'humanism'. These are related to our understanding of identity issues and are significant for an understanding of why terms such as 'personality' are problematic, as they may entail an essentialist view of individuals. Vivien Burr holds that Humanism:

refers to the idea that the person is a unified, coherent and rational agent who is the author of their own experience and its meaning. Humanism is essentialist; it assumes that there is an essence at the core of an individual that is unique, coherent and unchanging. But it also says that the individual's experience and the meaning it holds originates within the person, in their essential nature. 'Essential nature' here could refer to a number of things such as personality traits, attitudes, masculinity and so on (Burr 2003, 53-4).

A social constructionist approach attempts to move the focus from ideas of a distinctive essence of individuals to the social realm and linguistics. Language may contain elements that construct a person and language as above all a social phenomenon occurring in a context between people in which identity constructions take place. The self is therefore in constant flux, which it has to be if the self is, to a large extent, a product of social interactions and language (Burr 2003, 53-54). 'Some subject positions are more temporary or even floating and therefore who we are is constantly in flux, always dependent upon the changing flow of positions we negotiate within social interaction.' (Burr 2003, 120) 'With the poststructuralist view of language we are drawn into a view of talk, writing and social encounters as sites of struggle and conflict, where power relations are acted out and contested.' (Burr 2003, 54-55) This perspective is linked to the understanding of a discursive involvement of stakeholders in the formation of what is 'Islamic' or not, and to a more general struggle over interpretative authority in the context of religious traditions.

\section{Contemporary or historical focus in the history of religions}

In our understanding the criticism is sometimes voiced that Islamic studies scholars are currently focused on the contemporary historical setting, thus neglecting the study of history. Some historians of religions highlight this 
as part of a general trend in the contemporary study of religions. Of the German context Rüpke states:

Contemporary research increasingly tends to concentrate on current issues, for instance the relationship between religion and politics, religion and violence, religion and the mass media, religion and the environment (including the economic environment), or between religion and ethical demands and legal systems. ${ }^{7}$

One understanding of this criticism is that 'history' means ancient history, or at least 'older' than the present, and that 'history' is lost due to the focus on current versions of Islam. Even if this concern addressed by some scholars is appreciated, it is equally important to note that many scholars within the field of Islamic studies have language skills to approach sources not only in, for example, English or Swedish. Although scholars do not need to know hieroglyphs to do this, many have spent years mastering, for example, Arabic or Turkish. Moreover, most Nordic Islamic studies scholars have a training in the history of religions, which equips us to avoid addressing our objects of study in an ahistorical manner, and to perceive contemporary empirical material as historically situated.

It is important to recognise the immense emphasis within most historical and current Muslim interpretations on early Islamic history and sources. In the case of contemporary interpretations of Islam 'the past' is continuously drawn upon to inform the present as well as the future. In interpretations of Islam this takes place to such a large extent that in Muslim contexts the early history of Islam is universal, not bound to a certain period in time and events in the community, and the acts of the prophet Muhammad are to be individually or collectively emulated and translated into contemporary societies. Without a knowledge of these sources and Islamic history in general scholars would be unable to analyse contemporary phenomena that are considered Islamic. For example, studying the phenomenon of 'othering' in contemporary Muslim discourses is a field of research that concerns many scholars studying Islam and Muslims today. The polemics found in the contemporary discussion regarding 'othering' are often founded on medieval sources, dating from early Islamic history. Another distinctively contemporary example concerns the actions of the so-called Islamic State

7 This has been noted by Jörg Rüpke 285-6, who addresses the contemporary research focus on current issues. He refers to Spineto 2009, 47, cited here, and an analysis of German Religionswissenschaft with similar conclusions. (Wissenschaftsrat 2010.) 
and how the statements made by the self-proclaimed caliph Ibrahim (Abu Bakr al-Baghdadi, b. 1971) have been countered by current Muslim scholars from around the world in 'a letter to Baghdadi'. To analyse al-Baghdadi's arguments and the letter scholars need a thorough familiarity with early Islamic history, the development of the caliphate, jurisprudence, and the theological and ideological developments in the ideas of an 'Islamic state' or 'Islamic caliphate' that developed following the fall of the Ottoman Empire. A third and telling example is how this movement characterises Sufis and Shi'a Muslims as enemies of true Islam and rejects the use of reason in favour of a literal reading of revelation. ${ }^{8}$ To explain this, and the roots of such an interpretation, we need to access early sources. In our view a deeper knowledge of contemporary Islam in its various forms must include a study of its early history. However, if we are to make sense of how the term 'tradition' is used in various ways and for various reasons today, the starting point must be contemporary history. Hence, to construct a dichotomy between the words 'history' and 'contemporary' becomes meaningless, and any value judgment attached to 'historical' studies as being of more value than studies of the contemporary becomes scientifically irrelevant.

We acknowledge that narratives concerning history, among scholars as well as believers, arise in situations framed by contesting claims for legitimacy and authenticity, influencing identity-making and delimitation of in-groups and out-groups. A historiographical method in the study of religions approaches the present chronologically and regards the contemporary as a result of choices made in the past, drawing attention to the need to historically situate, or contextualise, empirical material. It is not so important in this context if the study starts in the contemporary era or at a particular distant historical moment. However, an understanding of the past is always informed by scholars' current questions (or what scholars study), and serves to create a definition of the present situation and to contain an orientation towards the future (Rüpke 2011). ${ }^{9}$

8 The rejection of Greek philosophy has its counterpart in the jurist Ibn Taymiyya (d. 1328). See Ibn Taymiyyah and Hallaq 1993.

9 This perspective is actually compatible with much of the more sociologically inclined perspectives prevalent today. For example, scholars using Social Movement Theories (SMT) acknowledge this in studies on strategies found in social movements to define a present problem, to present a solution to this problem, and to motivate participants to engage in solving the problem, i.e. mobilisation. The solution in social movements that can be characterised as religiously fundamentalist, for example, often addresses an immoral or capitalistic present, often labelled as a westernisation, that can be remedied with a correct understanding of a golden past that ought to be implemented in the present to reach an authentic future. See for example Wiktorowicz 2003. See also Olsson 2012 and 2014. 
Moreover, an ahistorical focus on the contemporary sometimes disturbs the authors of this article. In our opinion a focus on lived religion appears to be increasing that is partly due to the promotion of non-essentialist views of Islam and Muslims. The argument is that it is important to avoid generalisations, to study a limited number of individuals and their practices, and narratives about their religious tradition. This is certainly a significant field of study. However, it is regrettable that textual studies are not regarded as being as important as is the study of the religion lived by the many. Although Asad's notion of Islam as a discursive field rejects scholarly essentialist understandings of Islam, there is a scholarly need to acknowledge that there is an 'Islam out there', bound in time and space, to which Muslims and non-Muslims refer, under circumstances that relate to what Eickelman and Piscatori have termed an objectification of religion (Eickelman and Piscatori 1996, 38f). Such an acknowledgement does not imply that Islam is from a scholarly perspective universally or essentially defined, as Asad also states in his rejection of universal definitions of religion, mentioned above. It is not the case that Asad, or Edward Said for that matter, intends that scholars of Islam should all become ethnographers studying lived religion in order to avoid an Orientalist or essentialist position, but it has surely brought the idea to the fore that there is a need to study 'real' people and their practices, and not merely texts. Rather, what they address are the scholarly perspectives and assumptions that cause us to understand and reflect on what we study. In our opinion there is a need to call for an increased analysis of texts as part of contemporary lived religion. Jocelyne Cesari has discussed this in an article regarding research in which she comments on the ethnographic dominance in studies of lived religion:

The problem is that it is not possible to treat Islam as a mere artifact of anthropological study because Muslims identify with Islam (...). Like it or not, anthropologists and social scientists have to work with the universalist claims of Islam to a certain extent because Muslims themselves make such claims and continually calibrate their practices to them. In fact, references to what is right or wrong, just or unjust, possible or not possible within Islam are largely determined by sources and materials that anthropologists have unfortunately excluded from their domain of research. Although I agree with Abu Lughod that it is a healthy impulse to study a religion through what its practitioners say and do, it is by no means sufficient because the debates about the nature of Islam and what it means to be a Muslim themselves shape people's actions and discourse. Islamic texts and sources are both polyvocal 
and contradictory, and there are dialogues between texts and practices as well [as] discussions that are internal to the domain of practice (Cesari 2009, 16).

This suggests that we must avoid excluding the textual dimension in people's lives today when conducting research in the field of 'lived religion'. To fulfil Cesari's ideas the scholarly community at large would clearly benefit from a strengthened presence of historians of religions in the study of contemporary expressions of religion. In addition a study of the role of stakeholders' influence on interpretations of Islam would add an analytical layer demonstrating that scholarly examination of how Islam is understood and practised is not a question that can be determined by a study of things termed 'Islamic' or 'Muslim' only. The larger non-Muslim context is an important reference point not only for scholars of Islam, but also for Muslim producers of the religion. Hence, our point is threefold. We argue that it is certainly important to address non-Muslim stakeholders and their position with regard to understandings of Islam and Muslim practices, and to do this from a perspective in which the ambiguity and drudge of daily life in general is taken into account. However, we also state that a textual dimension is important if it is desired to give an account and analysis of contemporary Muslim life.

\section{Uncritical and neutral descriptors}

In our view one risk in regard to the politicisation of religion is that we are becoming uncritical: processes of politicisation influence what scholars choose to study. In relation to this it should come as no surprise that some scholars may present 'neutral' descriptions of a religious tradition, perhaps because of the political or human desire to make the world a better place. At the same time colonial guilt has long beset Islamic Studies - not least since Edward Said's Orientalism, published in 1978, which forced an ongoing selfcritical discussion among scholars of Islam. The result is that to critically analyse a religious tradition, or a part of it, may be seen as a humiliating assault on those belonging to this tradition, but avoiding such analysis risks reducing us to performing apologetics or avoiding challenge, and making the study of religions focus on 'the nice guys' or practices that are considered positive. Scholars of religion can thus act as religious interlocutors of what religion is, or ought to be.$^{10}$ In a sense it is an admirable mission to inform

10 As a parallel example, see Schielke (2010) for a critical discussion on how 'Islam' is understood and utilised in the field of the anthropology of Islam, where he argues that 'there is too much Islam in the anthropology of Islam' (Schielke 2010, 2). 
the public that not all Muslims are 'bad Muslims' as part of a postcolonial strategy of liberating Islam and Muslims from a stereotyped and negative image. By extension this may of course bring criticism from groups, like the Swedish Humanist Association, which oppose the presence of religion in the public space. They may claim that we are pro-Islam, uncritical Islamlovers, or even crypto-Muslims or they may say that we are Leftists or cultural relativists. We believe that this is also what Aaron Hughes wishes to highlight when he criticises apologetic approaches in Islamic studies in his two works Situating Islam and Theorizing Islam, and it highlights the need to subject our scholarly discourse and practice to critical inquiry. We also need to discuss what - if any - public role we should have.

\section{Public debates}

Perhaps it is enough to teach courses at universities that encourage our students to reflect critically on freedom and knowledge and hope that they will practise such ideals in their future lives. However, if scholars come to an understanding that they should participate in public debates, one significant question concerns whether historians of religions should uphold the specific perspectives to be brought into public discussion. Considering the above discussion, are we to retain a neutral or even detached stance concerning values, or should historians of religions advance values such as gender equality, human rights, and democracy? Or should he or she go even further and take a committed political stance in public discussions on religion? These questions can and should certainly be answered differently by individual scholars, but perhaps there are lessons, positive as well as negative, to draw from the experience of colleagues or from other academic disciplines such as political science and economics A key question concerns whether historians of religions are bound by any general and public discussions on religions. Does the discipline of the history of religions generate an understanding of religions that can contribute to public debate?

In this context, moreover, we should also like to point to an outcome of participation in public discussion and the general desire to disseminate research findings to a wider audience. What is stated and what is written becomes public in a completely different sense than if research findings are only published in the field's academic journals. One aspect of this is that engagement in public discussion in every media requires certain skills, and this involves more than explaining and analysing complex phenomena in a few 
words. However, this requires a pedagogical and professional training that is often neglected by academics and universities as being of a lesser value.

Another neglected area usually considered to be of lesser value concerns whether scholars of religion have a certain responsibility in their capacity as civil servants to contribute to policy-making or the training of civil servants in general. ${ }^{11}$ For example, how should we respond to requests from foreign ministries or other state authorities for briefings about recent developments in contemporary Muslim movements, or for reports for a state funded institution or think-tank on the role of mosques as vehicles for integration? In our case, working within the field of Islamic Studies, these possibilities and questions are always present and may influence how we choose research topics and how we approach and select our material. A further question we have to ask concerns who will respond to such requests if we do not. The point is not to glorify our knowledge and perspective, but to be open to discuss the role of academics and their relationship first to the state, but also to private institutions that feel a need for the scholarly knowledge produced by the broader field of the study of religions. Moreover, the increased visibility of research findings through popular publication outlets, the writing of reports, or participation in public discussions and social media makes them vulnerable. An implicit consequence of increased visibility is that statements, texts, or conclusions can be taken out of context and used to provide support for views not shared by scholars. Research findings may also be used by stakeholders, individuals, and/or groups, and become significant parts of the current production of religion.

If it is accepted that scholars of religions should engage in public debates on TV, radio, and the old and new media, scholars may need to develop their skills and expertise if they are to contribute their scientifically informed knowledge and present different perspectives on important matters in political debate and public discussion in general. For example, scholars should be able - and perhaps trained - to discuss the rise in Islamophobia and fascism, as well as the growing expression of fundamentalism, in Europe. From our perspective this is very much a feature of the 'politicisation of religion'. Moreover, critical or negative discussions on religion in the public space stem not only from a right-wing perspective, but also from the socalled New Atheists and a general public that may be suspicious of what they consider to be overtly religious practices. Such a perspective can be oppressive of others merely for their religious belonging and practice. The

11 In this respect it should be noted that Swedish higher learning institutions are all, more or less, state universities and their employees are state officials. 
idea that religious belonging per se creates irrational and violent individuals who constitute a danger to the free and rational world is not uncommon in secular society. These opinions are usually framed within discourses on what constitutes good and bad or true and false religion, and are associated with umbrella terms like 'the war on terror' in which 'religion' becomes a security issue. Participating in public discussion is, in a sense, part of the intellectual's responsibility. We therefore believe that there are legitimate reasons to avoid participation in debate in the public space and media if, for example, it proves too time-consuming and the result is difficult to quantify. However, if public discussion revolves around issues intimately related to the scholarly study of religions, it might be considered part of our academic and intellectual responsibility to participate, and silence on the part of historians of religions is not an option. It is unlikely that the general public's demand for knowledge concerning the historic or contemporary role of religions will disappear.

\section{What should we do?}

On the basis of all this we can therefore reflect on the current status of the history of religions, the role of historians of religions, and how the field might develop. Today this particular field within the broader field of the study of religions approaches its subject matter as temporal, historically situated, and socially constructed by humans and institutions that usually represent themselves as eternal, transcendent, spiritual, or divine. The history of religions is not merely descriptive, however - or we, at least, hold that it should not be. We believe there is a point in refraining from merely asking, where Islamism is concerned, what is seen as authentic Islam by some Muslims. In line with Armando Salvatore's argument we should be concerned rather with the 'what for' - analyse why they regard something as genuine and how they authenticate Islam as such (see Salvatore 1995, 194-195). Historians of religions might probe more than the what and the who with questions such as Who speaks? To whom? What is said (written, done...)? by also asking the why? Why did X say $\mathrm{Y}$ to $\mathrm{Z}$ ? What does the historic and contemporary empirical material tell us? In relation to this we stress the analytical aspects of locating power and agency, and this is of course the case for those scholars who use historical material from an ancient past, as well as those who focus on the historical material of the present. Furthermore, an analysis of power relationships and agency is important not only for a consideration of a religious tradition's explicit political interpretation and 
practice, but also for interpretation and practice that are not visible at first sight. Things pertaining to the ambiguities of the everyday life of people are in our view just as political as those speaking about a religious state or a religiously motivated and justified revolution.

A scientifically founded and critical approach to Islamic studies or the history of religions may result in criticism that affects what scholars choose to study, how that study is conducted, to whom findings are presented, and if scholarship is made available to a general audience. One allegation concerns scholarly reductionism. Considering our origins in the realm of theology, this is really nothing new. The claim that scholars of religions oversimplify complex phenomena is a strategy to silence critical voices. However, it is important to uphold the principle that scholars are not in any way obliged to consider any confessional claim of transcendence or sacredness as anything other than a truth claim and as expressions of power in a historic or contemporary situation. Furthermore, the claim itself is an empirical object that we need to study through historical and critical inquiry. Moreover, we should be continuously self-critical of our research to avoid falling into an empathetic trap or studying only those expressions of religion we personally prefer, like to have 'dialogue' with, or about which we are able to write positively. In sum, to paraphrase Russell McCutcheon, scholars are not meant to be caretakers. We are to be critical inquirers providing independent and informed analysis in the context of the scholarly community and society at large. Why else should we be financed by tax money?

\section{A critical perspective}

The above arguments correspond to Thomas B. Ellis's understanding of the contemporary field of the study of religions as being dominated by two approaches. The first refers to non-natural universals, advocated by those with an essentialist view of religion, 'a philosophically suspect theological agenda' (Ellis 2008, 281), that is 'beyond empirical verification or falsification' (Ellis 2008, 283). Such a perspective must be shunned by the history of religions. Ellis assigns to the category of non-naturalists 'all theologians and religious practitioners of the supernaturalist variety' and these 'are the people about whom and not with whom scholars of religion talk. To confuse this issue - the very issue at the heart of appeals to dialogical studies and their conjunctive constructions - is to confuse the subject of explanation with the means of explanation.' (Ellis 2008, 287. This reflects the discussion by McCutcheon 2006.) In the Swedish context this perspective is not espe- 
cially common in the broader study of religions. However, it overlaps with approaches cultivated primarily in departments of theology.

The second category is a particularist ethnographical approach to culture, 'a quasi-dogmatic postmodern anxiety about natural generalizations' (Ellis 2008, 281). This is what Jonathan Z. Smith critically calls an 'ethos of particularism' that designates the approach to cultures as particular and rejects cross-cultural comparisons (Smith 2004, 368). Dense descriptions where language skills and fieldwork are the primary competences of scholars are privileged in such approaches (Discussed in Ellis 2008, 280 who also mentions Smith 2004). This is described by Thomas B. Ellis as a postcolonial 'expression of neo-colonial ambition. Guilt-ridden, theoretical hesitance.' (Ellis 2008, 281) Smith argues that it is an ethos that rejects classification, comparison, and explanation and the result is the requirement to listen to the Other, to dialogue, which is seen as the antidote to imperialism (Ellis 2008, 281). This resembles, according to Ellis, the discussion by Russell T. McCutcheon mentioned above (Ellis 2008, 282). Moreover, Ellis points out that this perspective also encourages scholars to perceive the Other's position as a potential self-position, and as such results in a kind of ecumenical dialogue (Ellis 2008, 281-282). Among such scholars are, for example, Gavin Flood, Diana Eck, and Robert Orsi. They advocate a dialogue and 'hospitality', as well as a need to re-examine their own tradition and benefit from the study of Others. As such this approach strives to be 'liberating' (Ellis 2008,282 ) and a part of engaged research, but, in our opinion, is not one conducted in a critical academic manner.

The above implies that there is at least a third approach. This approach does not call for an essentialist understanding of 'religion' and it does not advocate an empathetic dialogical research agenda. Rather, it calls for a perspective on 'religion' founded on an outlook in which religion is a social phenomenon in its broadest sense related to power. Hence, a critical perspective needs to include aspects of power. Research that aims to empower or to contribute to the liberation of someone or something is not contrary to such an approach, but it needs to take the topics discussed by many of the historians of religions quoted in this article seriously and reflectively, realising that everything we do is re-presenting 'the Other', even when we have an ambition to 'give them a voice'. Moreover, we should also self-critically reflect on and clarify why we as scholars are interested in some fields and questions, and why we avoid others. As McCutcheon argues, 'the world around us does not jump up and tell us what is important and interesting' (McCutcheon 2001, 87). 
At the heart of the discussion here are methodological views and stances concerning how engaged a researcher should be and in what ways. Engaged research can be empowering. For example, researchers can illustrate unequal power relationships, and research results can function as a social critique. This can be accomplished with or without an explication of normative suggestions about how to solve the problem in focus - where the first approach is probably easier to defend as being as neutral and objective as a scholarly perspective can be within the study of religions. The second may risk being criticised as activism and as ideological (supposedly non-neutral) research, even if the difference between them may not always be clear.

A problematic methodological question is the extent to which scholars have the right to speak on behalf of other people, no matter how well intentioned they may be. Some social constructionists favour the view that insiders should be given voices, and that the scholar's account of a matter should not be the only one presented. This would, they argue, bring about a more democratic and coequal form of research (Burr 2003, 155ff.). However, although the idea that stakeholders' voices should be heard is widespread, it is important to remember that it is the scholars who decide who will be heard and what aspects of their voices will be chosen (McCutcheon 2006, 734). We do not agree with the idea of some 'relativists' that all languages are equally valid. We suggest that scholars need an analytical scientific language that can be used cross-culturally to produce generalisable outcomes, albeit not in the sense of grand theories (see for example Hammer and Sørensen 2010, 53). Moreover, when a voice is allowed to be heard it is usually accompanied by an explanation: 'We put our words into their mouths and, for whatever reason, fail to recognize the sound of our own voices.' (McCutcheon 2006, 740) We do not simply describe or present reality as it is. Rather, a representation is always involved, what we do is to represent only one version of several. It is therefore better described as a 'translation' (McCutcheon 2006, $741 \mathrm{ff}$.). The attentive reader may have sensed that the authors of this article are hesitant towards perspectives and methods that can be characterised as 'postcolonial', deconstructive, or relativist. This stems from a language-use based emphatically on the desire to avoid the pretence of having an objective scientific language that is 'better' than other languages to describe the world, an ethnocentric view. Spineto states that if we are to struggle against ethnocentrism a logical consequence will be a critical analysis of scholarly patterns of knowledge production in our own environments - a task that will be performed with tools manufactured and conceptualised by European and North American academia. However, these tools are more or less used at a 
global level. He concludes: 'Perhaps, then, the tradition of historico-religious studies may provide a solution to these problems.' (Spineto 2009, 48.)

This perspective is perhaps a more pressing issue for scholars with a focus on the political and/or Islamist interpretations and practices of Islam to address, given the current tense global situation and 'the war on terror'. In discussing the study of cultural processes Spineto states that the search for models is founded on complementary data and linked to historical data. He also highlights the need to create a continuity between the studies of the contemporary and of the past 'provided that they are redirected to respond to the needs of present culture' (Spineto 2009, 49). Spineto finally suggests an 'interdisciplinary dialogue' that would apply 'research tools with an awareness of their social and cultural implications' (Spineto 2009, 49). Hence, a historical-critical method and historiographical awareness are crucial if the problems we all recognise concerning matters in the study of religions or society in general are to be addressed, but this will be done from a position in which 'history' is produced in the present.

If we wish the history of religions to be a critical discipline, we need to consider these points. If we do not, we risk finding ourselves in merely nonnaturalist theological or particularist ethnographical approaches oriented towards empathy and dialogue.

\section{Concluding comments}

The authors believe that it is not enough for us as historians of religions merely to describe and critically interpret the 'world of religion'. The history of religions appears today as a discipline in the backwater of Islamic studies and in the broader field of the study of religions. Perhaps it would be good to adopt a more self-critical approach that avoids the elitism that only contributes to the fading of the status of the discipline in general. A first and possibly decisive step might be to embrace a more interdisciplinary approach and learn from other disciplines' study of religions. A second might be to reinvigorate the discipline by providing society with informed knowledge about the historic and contemporary role of religion. It is not fanciful to think that a greater presence of historians of religions in public and academic discussions on religion would improve the likelihood of increased funding. The question of whether historians of religion are exempt from an intellectual or moral obligation to improve life conditions in general is certainly linked to the latter. ${ }^{12}$

12 Cf. Theses on Feuerbach, 11, 'Philosophers have hitherto only interpreted the world in various ways; the point is to change it.' Marx 1845. 
SUSANNE OLSSON is Professor of History of Religions at Stockholm University, Sweden.

E-mail: susanne.olsson@rel.su.se

LEIF ERIK STENBERG is Professor of Islamology and Director for Centre for Middle Eastern studies at Lund University. E-mail: leif.stenberg@cme.lu.se.

Bibliography

Asad, Talal

1993 Genealogies of Religion: Discipline and Reasons of Power in Christianity and Islam. London: Johns Hopkins University Press.

2006 Responses - David Scott and Charles Hirschkind (eds), Powers of the Secular Modern: Talal Asad and His Interlocutors, 206-41. Stanford: Stanford University Press.

Bayat, Asef

2007 Making Islam Democratic: Social Movements and the Post-Islamist Turn. Stanford, California: Stanford University Press.

Bell, Catherine

1997 Ritual: Dimensions and Perspectives. New York: Oxford University Press.

2006 Culture: What Does One Do With It Now? - Method and Theory in the Study of Religion 18 (4), 315-24.

Beyer, Peter

1994 Religion and Globalisation. London: Sage Publications.

2006 Religions in global society. London: Routledge.

\section{Burr, Vivien}

2003 Social Constructionism. 2nd ed. London and New York: Routledge.

\section{Cesari, Jocelyne}

2009 Islam in the West: from immigration to global Islam. Harvard Middle Eastern and Islamic Review 8, 148-75.

\section{Curtis IV, Edward E.}

2014 Ode to Islamic Studies: Its Allure, Its Danger, Its Power. - Bulletin for the Study of Religion. <http://www.equinoxpub.com/blog/2014/05/ ode-to-islamic-studies-its-allure-its-danger-its-power-reflections-onislamic-studies/>, accessed 9 September 2015.

Eickelman, Dale F. \& James Piscatori

1996 Muslim Politics. Princeton: Princeton University Press. 


\section{Ellis, Thomas B.}

2008 Of And and Of: the Politics of Grammar and the Study of Religion. Method and Theory in the Study of Religion 20, 270-90.

Flood, Gavin

1999 Beyond phenomenology: rethinking the study of religion. London: Cassell.

\section{Geertz, Clifford}

1973 The Interpretation of Cultures: Selected Essays. New York: Basic Books.

Hammer, Olav and Sørensen, Jesper

2010 Religion i människors medvetanden och samhällen. Lund: Studentlitteratur.

\section{Hughes, Aaron}

2007 Situating Islam: the Past and Future of an Academic Discipline. London: Equinox.

2012 Theorizing Islam: Disciplinary Deconstruction and Reconstruction. Sheffield: Equinox.

\section{Ibn Taymīyah, Aḥmad ibn 'Abd al-Ḥalīm and Hallaq, Wael B.}

1993 Ibn Taymiyya against the Greek Logicians. Translated with an introduction and notes by Wael B. Hallaq Oxford: Clarendon Press

\section{Johnson, Greg}

2008 Authenticity, Invention, Articulation: Theorizing Contemporary Hawaiian Traditions from the Outside - Method and Theory in the Study of Religion 20, 243-58.

\section{Letter to Baghdadi}

2014 Open letter to Dr. Ibrahim Awwad Al-Badri, alias 'Abu Bakr Al-Baghdadi', And to the fighters and followers of the self-declared 'Islamic State' AlBaghdadi. <http://www.lettertobaghdadi.com/>, accessed 4 August 2015.

\section{Lincoln, Bruce}

2003 Holy Terrors: Thinking about Religion after September 11. Chicago: the University of Chicago Press.

\section{Marx, Karl}

1845 Theses on Feuerbach. <https://www.marxists.org/archive/marx/ works/1845/theses/>, accessed 17 September 2015.

\section{McCutcheon, Russel T.}

2006 'It's a Lie. There's No Truth in It! It's a Sin!' On the Limits of the Humanistic study of Religion and the Costs of Saving Others from Themselves - Journal of the American Academy of Religion, 74 (3), 720-50.

2003 The Discipline of Religion: Structure, Meaning, Rhetoric. London and New York: Routledge 
2001 Critics, not Caretakers: Redescribing the Public Study of Religion. Albany: State University of New York Press.

1997 Manufacturing Religion: the Discourse on Sui Generis Religion and the Politics of Nostalgia. Oxford: Oxford University Press.

\section{McKinnon, Andrew M.}

2002 Sociological Definitions, Language Games, and the 'Essence' of Religion. - Method and Theory in the Study of Religion 14 (1), 61-83.

\section{Olsson, Susanne}

2015 Preaching Islamic Revival: 'Amr Khaled, Mass Media and Social Change in Egypt. London: IB Tauris.

2014 Proselytizing Islam - Problematizing 'Salafism' - The Muslim World, 104 (1-2), 171-97.

2012 A hijra Within. - Comparative Islamic Studies 8 (1-2), 71-92.

Rüpke, Jörg

2011 History - Michael Stausberg and Steven Engler (eds), The Routledge Handbook of Research Methods in the Study of Religions, 285-309. London \& New York: Routledge.

Said, E.W.

1978 Orientalism. London: Penguin Books Ltd.

\section{Salvatore, Armando}

1995 The Rational Authentication of Turath in Contemporary Arab Thought: Muhammad al-Jabiri and Hasan Hanafi. - Muslim World 85 (3-4), 191-214.

\section{Schielke, Samuli}

2010 Second Thoughts About the Anthropology of Islam, or How to Make Sense of Grand Schemes in Everyday Life. Berlin: Centrum Moderner Orient, Working Papers, No. 2.

\section{Smith, Jonathan Z.}

2004 Relating Religion: Essays in the study of religion. Chicago: University of Chicago Press.

\section{Smith, Wilfred Cantwell}

1959 The Comparative Study of Religion: Whither - and Why? - Mircea Eliade and Joseph Kitagawa (eds), The History of Religions: Essays in Methodology, 31-58. Chicago: University of Chicago Press.

\section{Spineto, Natale}

2009 Comparative Studies in the History of Religions Today: Continuity with the Past and New Approaches. - Historia Religionum 1, 41-50. 


\section{Stenberg, Leif}

1996 The Islamization of Science: Four Muslim Positions Developing an Islamic Modernity. Lund Studies in History of Religions 6. Stockholm: Almqvist \& Wiksell International.

\section{Taylor, Mark C.}

2004 Defining religion. The Chronicle of Higher Education 51 (11) November 5.

\section{Waardenburg, Jacques}

2003 Muslims and Others: Relations in Context. Berlin and New York: Walter de Gruyter.

\section{Wiktorowicz, Quintan}

2003 Introduction: Islamic Activism and Social Movement Theory. Quintan Wiktorowicz (ed), Islamic Activism: a Social Movement Theory Approach, 1-33, Bloomington: Indiana University Press.

\section{Wissenschaftsrat}

2010 Empfehlungen zur Weiterentwicklung von Theologien und religionsbezogenen Wissenschaften an deutschen Hochschulen. Berlin. 
